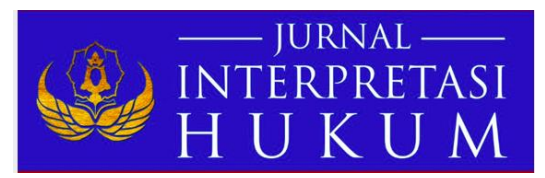

\title{
AKIBAT HUKUM MALPRAKTIK YANG DILAKUKAN OLEH TENAGA MEDIS
}

\author{
Julius Roland Lajar, Anak Agung Sagung Laksmi Dewi, I Made Minggu Widyantara \\ Fakultas Hukum Universitas Warmadewa, Denpasar - Bali, Indonesia
}

\begin{abstract}
Abstrak
Malpraktik merupakan suatu tindakan kelalaian atau suatu tindakan dengan standar operasional prosedur yang benar tetapi mengakibatkan kerugian pada konsumen dalam ini adalah pasien dan ini dapat mengancam kesehatan dan keselamatan pasien. Malpraktik yang dilakukan oleh tenaga medis tentunya sangat merugikan pihak-pihak yang membutuhkan penanganan medis dan sangat mempengaruhi kaulitas rumah sakit yang tentunya merupakan central dari segala tindakan medis. Berdasarkan hal ini, penelitian ini mengkaji tentang bagaimana pengaturan hukum bagi tenaga medis yang melakukan malpraktik dan bagaimana sanksi pidannya. Untuk menjawab permasalahan ini digunakan metode penelitian normatif dengan melakukan pendekatan perundang-undangan yang mengkaji peraturan perundang-undangan yang berlaku dan pendekatan konseptual untuk mengkaji bahan-bahan kepustakaan dalam bentuk teori-teori dan para pendapat pakar hukum. Pengaturan hukum bagi tindakan malpraktik oleh tenaga medis diatur dalam beberapa peraturan perundang-undangan yang memberikan dasar-dasar pedoman seputar tindakan malpraktik yang dilakukan oleh tenaga medis. Adapun peraturan tersebut ditemukan dalam undang-undang kedokteran dan undang-undang kesehatan dimana memberikan suatu kepastian hukum bagi yang dirugikan. Hal ini merupakan ciri dari hukum itu sendiri dalam menegakkan keadilan. Perbuatan malpraktik yang dilakukan oleh tenaga kesehatan sudah diatur hukumnya dalam peraturan perundang-undang Nomor 23 Tahun 1992 tentang Kesehatan dan Kode Etik Kedokteran yang berlaku. Selain itu terdapat sanksi terhadap perbuatan tindakan tenaga medis yang melakukan malpraktik, antara lain yaitu sanksi pidana, sanksi perdata, sanksi administrasi dan sanksi moral.
\end{abstract}

Kata Kunci: Akibat Hukum; Malpraktik; Tenaga Medis

\begin{abstract}
Malpractice refers to an act of negligence or an act with the correct standard operating procedures but causes harm to consumers, in this case the patients and this can threaten the health and safety of the patient. Malpractice committed by medical personnel is certainly very detrimental to those who need medical treatment and greatly affects the hospital's integrity which is certainly the center for all medical actions. Based on this, this study examines what the legal regulatory for medical personnel who commit malpractice and how to sanction his speech are. To uncover the issues a normative research method is used by applying the legislative approach that examines the applicable laws and regulations and a conceptual approach to reviewing library materials in the form of theories and opinions of legal experts. The legal regulatory for malpractice actions by medical personnel are regulated in several laws and regulations providing basic guidelines regarding malpractice actions committed by medical personnel. The regulations are found in the medical and health laws which provide legal certainty for the injured. This is a characteristic of the law itself in upholding justice. Malpractice acts committed by health workers have been regulated in the legislation No. 23 of 1992 concerning Health and the Medical Code of Conduct in force. In addition there are sanctions for the actions of medical personnel commiting malpractice, including criminal sanctions, civil sanctions, administrative sanctions and moral sanctions.
\end{abstract}

Keywords: Legal Consequence; Malpractice; Medical Personnel

\section{PENDAHULUAN}

Tindakan malpraktik merupakan kesalahan atau kelalaian yang dibuat secara sengaja maupun tidak sengaja oleh tenaga medis dapat mengakibatkan kerugian kesehatan dan keselamatan seorang pasien 
yang sedang ditanganinya (Sibarani, 2017). Hal ini sangat mempengaruhi kualitas tenaga medis di mata masyarakat luas dan tindakan ini juga dapat mempengaruhi kualistas rumah sakit dalam menanggani masyarakat pada umumnya. Di samping itu malpraktik juga sangat bertentangan dengan hukum karena tidak sesuai dengan Standar Operasional Prosedur (SOP) (Michel \& Mangkey, 2014), dimana setiap tenaga medis diharuskan dan berkewajiban untuk selalu memberikan pelayanan terbaik bagi pasien yang membutuhkan penanganan medis, karena ini merupakan salah satu standar operasional prosedur (SOP) yang harus dan wajib dilakukan oleh tenaga medis dalam menangani para pasien sesuai Peraturan Perundang-undangan yang berlaku.

Profesionalisme dari penanganan tenaga medis terhadap pasien sangat menentukan kinerja seorang tenaga medis di mata masyarakat luas oleh karena itu dibutuhkan tenaga medis yang profesional dan berpengalaman dalam menangani pasien agar tidak terjadi dugaan malpraktik oleh masyarakat atau kesalahan dalam menangani para pasien sehingga merugikan pasien. Dilihat dari kejadian-kejadian sebelumnya hingga Maret 2011 Majelis Kehormatan Disiplin Kedokteran Indonesia (MKDKI) telah menanggani 127 pengaduan kasus pelanggaran disiplin yang dilakukan oleh dokter maupun tenaga medis (Andryawan, 2016). Dari angka tersebut sekitar 80 persen disebabkan kurangnya komunikasi antara dokter atau tenaga medis dengan pasien. Bila dirinci disiplin ilmu yang diadukan, yang paling banyak adalah dokter umum (48 kasus) pengaduan oleh masyarakat. Dalam hal ini dokter dan pasien harus saling terbuka dalam melakukan penanganan medis tersebut sehingga terhindar dari kesalahan dan atau kelalaian yang diduga sebagai malpraktik dilakukan oleh tenaga medis, sehingga perlu adanya payung hukum untuk mengatur tindakan atau kelalaian yang dilakukan oleh tenaga kesehatan. Untuk itu keberadaan hukum kesehatan sangatlah membawa pengaruh yang besar terhadap pembangunan, khususnya di bidang kesehatan termasuk hukum Lex Specialis yang melindungi secara khusus tugas profesi kesehatan (provider) dalam program pelayanan kesehatan manusia ke arah tujuan deklarasi Health For All dan perlindungan secara khusus terhadap pasien (receiver) untuk mendapatkan pelayanan kesehatan (Kijanti, 2009; 14). Dan Undang-undang No 36 Tahun 2009 tentang tenaga kesehatan merupakan peraturan terhadap tenaga medis atau tenaga kesehatan yang melakukan tindakan malpraktik.

Beberapa kajian tentang malpraktik telah mendominasi kajian di bidang kesehatan dalam sau dekade terakhir. Sebagai tenaga kesehatan, dokter juga perlu mendapat perlindungan hukum dalam memberikan pelayanan kesehatan (Michel \& Mangkey, 2014). Kajian lain mengkaji tentang perlindungan hukum bagi pasien layanan medis yang menjadi korban malpraktik (Nurdin, 2015). Hukum malpraktik wajib mendapat penegakan melalui mediasi penal (Fitriono dkk., 2016). Kajian lain mengkaji tentang perlindungan hukum bagi profesi dokter dalam penyelesaian sengketa medis (Trisnadi, 2016). Perlindungan hukum terhadap pasien korban tindakan malpraktik juga perlu ditinjau dari sudut pandang hukum Indonesia (Sibarani, 2017). Tanggung jawab dokter atas tindakan malpraktik dalam memberikan pelayanan medis juga dapat dilihat dari perspektif hukum perdata (Riza, 2018). Tindakan melawan hukum dan malpraktik oleh dokter wajib dipertanggungjawabkan oleh tenaga kesehatan yang bersangkutan (Hadi, 2018).

Kajian kali ini mengkaji tentang: (1) Bagaimana pengaturan hukum bagi tenaga medis yang melakukan malpraktik? (2) Bagaimana sanksi pidana bagi tenaga medis yang melakukan tindakan malpraktik? Adapun tujuan penelitian terdiri dari tujuan yang umum dan tujuan khusus. Tujuan umum meliputi: (1) untuk melatih kemampuan mahasiswa dalam menyatakan pikiran secara tertulis; (2) untuk menerapkan setiap ilmu yang diperoleh selama dalam perkuliahan; (3) untuk melaksanakan Tri Dharma perguruan tinggi khususnya pada bidang penelitian yang dilakukan oleh mahasiswa. Tujuan khusunya meliputi (1) untuk mengetahui mengenai pengaturan hukum bagi tenaga medis yang melakukan malpraktik; (2) untuk mengetahui akibat hukum bagi tenaga medis yang melakukan malpraktik.

Beberapa menfaat dari penelitian terbagi dalam dua jenis, yaitu manfaat teoretis dan manfaat praktis. Manfaat teoretis mencakup (1) agar penelitian ini dapat memberikan manfaat kepada pengembangan ilmu pengetahuan dibidang ilmu hukum; (2) agar hasil penelitian ini dapat menambah refrensi atau literature mengenai suatu tindakan malpraktik yang dilakukan oleh tenaga medis dalam melakukan praktik kesehatan. Manfaat praktis terdiri dari (1) tulisan ini bagi peneliti untuk menerapkan ilmu yang diperoleh pada bangku kuliah sekaligus melatih dan mengembangkan pengetahuan maupun 
wawasan hukum; (2) bagi masyarakat hasil penelitian ini diharapkan menjadi informasi yang bermanfaat kedepannya dalam menggunakan tenaga medis; dan (3) bagi pemerintah dari hasil penelitian ini diharapkan memperjelas pengaturan pekerjaan tenaga medis khususnya dokter dalam melakukan pengawasan terhadap tindakan malpraktik dari tenaga medis.

\section{METODE PENELITIAN}

Jenis penelitian ini merupakan jenis penelitian normatif, tujuannya ialah menemukan peraturan perundang-undangan yang selanjutnya dikaji dengan permasalahan yang sesuai dengan masalah pokok dalam penelitian tersebut. Sedangkan pendekatan masalahnya ialah pendekatan perundang-undangan dan pendekatan konseptual. Pendekatan perundang-undangan dimaksud adalah pendekatan yang dilakukan atas dasar ketentuan hukum positif Indonesia dan norma-norma yang berlaku. Sedangkan pendekatan konseptual adalah mengacu pada asas-asas konsep seputar permasalahan yang menjadi pembahasan.

1. Sumber bahan hukum primer yaitu bahan hukum yang mengikat meliputi peraturan pokok dalam hukum pidana dan pengaturan pokok Undang-undang kesehatan yang menjadi landasan bagi pelaku malpraktik yang dilakukan oleh tenaga medis berupa sanksi dan standar operasional prosedur atau (SOP).

2. Bahan Hukum sekunder yaitu dikaji literatur yang berupa buku-buku hukum, pendapat para serjana atau ahli yang sesuai dengan pokok masalah yang dibahas.

3. Bahan hukum tersier yaitu meliputi kamus hukum, majalah hukum yang dapat menunjang pokok pembahasan tersebut.

Teknik pengumpulan bahan hukum yang dimaksud adalah pengumpulan datadengan cara studi kepustakaan dimana penulis memperolehnya dengan cara membaca, memahami, mengidentifikasi, mempelajari dan pemahaman terhadap apa yang dilihat di dalam bahan-bahan hukum sesuai dengan topik permasalahan yang dikaji penulis tersebut. Analisis yang dimaksud yaitu deskriptif, di mana penulis menjabarkan permasalahan, memberikan pandangan dan menyelesaikan permasalahan tersebut dengan menarik kesimpulan.

\section{HASIL PENELITIAN DAN PEMBAHASAN}

\section{Pengaturan Hukum bagi Tenaga Medis yang Melakukan Malpraktik}

Malpraktik pada dasarnya tidak hanya dilakukan oleh profesi kedokteran melainkan juga diprofesi lain seperti perbankan, pengacara, akuntan publik dan wartawan dan lain sebagainya. Hal ini didasari dengan adanya potensi-potensi untuk melakukan hal yang dapat merugikan pihak lain, menurut kamus hukum Black Law Dictionary merumuskan malpraktik sebagai Any Professional misconduct, Unreasonable lack of Skill or Fidelity in Professional or judiacry duties, evil or illegal or immoral conduct artinya perbuatan jahat dari seseorang ahli, kekurangan dalam keterampilan di bawah standar atau tidak cermatnya seorang ahli dalam menjalankan kewajibannya secara hukum, praktek salah atau illegal atau perbuatan yang tidak bermoral (Arifko, 2014; 107). Secara etimologi Malpraktik berasal dari kata malpractice artinya cara mengobati yang salah atau tindakan tidak benar dan tidak sesuai dengan standar operasioanl prosedur yang ada.

Dalam bidang kesehatan, malpraktik medis merupakan tindakan dari tenaga medis yang profesional tetapi tindakan tersebut merugikan seseorang atau pasien yang sedang ditanganinya. Ini merupakan bagian dari pelanggaran kode etik yang dilakukan oleh tenaga medis dalam melakukan kewajibannya dalam melayani pasien. Sedangkan defenisi dari malpraktik itu adalah: kesalahan atau kelalaian yang dilakukan oleh tenaga kesehatan atau tenaga medis dalam melaksanakan profesinya yang tidak sesuai dengan standar profesi dan standar prosedur operasional, akibat kelalaian atau kesalahan tersebut pasien memderita luka berat, cacat bahkan meninggal dunia.

Perkembangan Indonesia saat ini kalau dilihat dari kasus malpraktik dilakukan oleh tenaga medis sebagai pelaku yang melakukan pelanggaran bisa bersifat pidana, perdata dan administrasi, dengan demikian malpraktik dibagi menjadi tiga (3) golongan besar yaitu Malpraktik medik (medical malpractice), malpraktik etik (Ethical malpractice) dan malpraktik yuridik (juridical malpractice), dimana malpraktik yuridik dibagi menjadi tiga yaitu: Malpraktik perdata, malpraktik pidana dan 
malpraktik administrasi dimana masing-masing memiliki sifat sama dimana merugikan pihak lain dan melanggar standar operasional prosedur yang berlaku (Mucthar, 2016; 177).

Sejak tahun 2006 hingga 2012, tercatat ada 183 kasus kelalaian medis atau malpraktik medis yang dilakukan oleh tenaga medis dalam hal ini dokter maupun perawat diseluruh Indonesia dan ada berbagai macam hal dan faktor yang menyebapkan timbulnya malpraktik tersebut adalah standar profesi kedokteran, dimana harus memliki kemampuan diatas rata-rata dan ketentuan umum yang mumpuni sehingga apa yang dilakukan oleh tenaga medis atau dokter betul-betul dapat memberikan hasil yang baik. Selain itu standar operasional prosedur juga merupakan suatu perangkat instruksi/langkah-langkah yang dilakukan untuk menyelesaikan suatu proses kerja rutinitas tertentu dan informasi antara dokter dan pasien agar saling terbuka dalam pelayanan medis tersebut.

Selain itu juga ada beberapa faktor lain penyebab terjadinya tindak pidana malpraktik seperti kelalaian yang dilakukan dengan kurangnya kehati-hatian dan adanya kesengajaan yang sebenarnya tidak dikehendaki oleh tenaga medis itu sendiri dan kurangnya pengetahuan dan pengalaman dari seorang tenaga medis tentu saja di harapkan memiliki kemampuan, pengetahuan dan keterampilan dibidang kesehatan, ada juga faktor ekonomi dan rutinitas dapat menimbukan terjadinya malpraktik tersebut.

Selain dari pada faktor dan hal lain yang menyebabkan terjadinya malpraktik ada juga unsurunsur melawan hukum, seperti adanya unsur kesengajaan, unsur kelalaian, dan tidak ada alasan pembenar atau pemaaf seperti, membela diri, alasan tidak waras dan lain-lain, unsur kelalaian tersebut diatas terjadi ketika terpenuhinya beberapa hal pokok seperti, adanya perbuatan atau mengabaikan sesuatu yang harus dilakukan, tidak menjalankan kewajiban ketidak hati-hatian dan adanya kerugian bagi orang lain (Badlrujaman, 2001; 47).

Akibat hukum ketika orang mengalami kerugian terhadap malpraktik tersebut, orang karena kesalahanya tersebut menerbitkan kerugian itu untuk mengantikan kerugian tersebut, dari segi yuridis ganti rugi dalam hukum itu ada dua hal antara lain konsep ganti rugi karena wanprestasi dan konsep ganti rugi Karena perikatan berdasarkan Undang-undang termasuk perbuatan melawan hukum, kerugian tersebut memang harus dibuktikan sehingga seseorang diwajibkan untuk membayarnya, dimana dalam perbuatan melanggar hukum dapat berupa ganti rugi meterill dan non materill.

Pengaturan hukum merupakan sebuah dasar landasan untuk memberikan jaminan hukum terhadap adanya kepastian hukum agar terciptanya cita-cita hukum yaitu keadilan, dan sebaliknya setiap pelanggaran hukum sudah tentu mendapatkan sanksi sesuai dengan peraturan perundang-undangan yang berlaku, dengan demikian setiap tindakan malpraktik yang dilakukan oleh tenaga medis yang dapat merugikan pasien atau menimbulkan luka berat pada tubuh pasien merupakan pelanggaran terhadap peraturan perundang-undangan yang berlaku dan pelanggaran terhadap kode etik kedokteran. Hal ini juga dapat menimbulkan berbagai macam tangapan negatif dari masyarakat sehingga dapat mempengaruhi kepercayaan masyarakat terhadap tenaga medis maupun rumah sakit, selain itu efek dari pada tindakan malpraktik oleh tenaga medis ini dapat menimbulkan tanggung jawab besar terhadap, pribadi, kelompok dan institusi sehingga mempunyai tanggung jawab bersama dalam menghadapi masalah tersebut.

\section{Sanksi Pidana bagi Tenaga Medis yang Melakukan Tindakan Malpraktik}

Tindakan malpraktik yang dilakukan oleh tenaga kesehatan sudah diatur hukumnya dalam peraturan perundang-undang Nomor 23 Tahun 1992 tentang kesehatan dan kode etik kedokteran yang berlaku selain itu juga adapun sanksi terhadap perbuatan tindakan tenaga medis yang melakukan malpraktik, sanksi yang dimaksud antara lain, sanksi pidana, sanksi perdata, sanksi administrasi dan sanksi moral, dimana sanksi-sanksi tersebut berupa pidana penjara, ganti rugi, teguran, denda atau pembekuan izin akibat kelalaian tersebut dan pelanggaran terhadap norma dan moralitas (Syah, 2019; 129). Terhadap sanksi administrasi umumnya dikenakan kepada pelanggaran diklasifikasikan pelanggaran administrasi bersifat privat yang dijatuhkan oleh aparatur atau pejabat tata usaha negara, sanksi teguran merupakan teguran secara lisan dan tertulis.

Penjatuhan sanksi teguran ini kepada pihak penerima sanksi harus diberitahu jenis kesalahanya. Jenis sanksi ini bersifat ringan dan kepada pihak yang ditegur masih diberikan kesempatan untuk memperbaiki diri, adapula sanksi dalam pembekuan hingga pencabutan sertifikat, sanksi ini merupakan 
penghentian dalam jangka waktu sementara dan selamanya, apabila untuk sementara sanksi tersebut mempunyai batas waktu dan sanksi tersebut dianggap selesai ketika penerima sanksi sudah melewati batas waktu tersebut dan kembali pada kondisi semula yakni kondisi sebagaimana sebelum menerima sanksi tersebut, sanksi administrasi yang terakhir adalah sanksi denda, besar kecilnya denda akan ditentukan oleh hukum yang mengaturnya karena setiap ketentuan mempunyai dasar hukum dan kriteria masing-masing.

Perbuatan tenaga medis yang melakukan tindakan malpraktik ini juga menimbulkan suatu sanksi tidak tertulis yaitu sanksi moral, sanksi moral memang tidak tertulis. Oleh karena itu, pemberian sanksi juga tidak tertulis. Kendati pun tidak tertulis, itu memiliki kekuatan yang dasyat karena mempengaruhi kualitas tenaga medis di mata masyarakat.

Tenaga medis pada dasarnya sudah memiliki dasar hukum atau payung hukum untuk memberikan jaminan hukum kepada tenaga medis atau tenaga kesehatan pada umumnya yang melakukan profesi dalam melakukan tindakan medis atau melakukan pelayanan kesehatan, karena tenaga medis merupakan komponen utama pemberi pelayanan kesehatan kepada masyarakat dalam rangka untuk mencapai suatu tujuan dalam melakukan pembangunan kesehatan yang sesuai dengan tujuan nasional sebagaimana sudah diamanatkan oleh konstitusi (Kijanti, 2009; 141). Hukum positif Indonesia terdapat beberapa peraturan perundang-undang yang berkaitan dengan perlindungan hukum terhadap tenaga medis atau tenaga kesehatan dalam melakukan profesi.

\section{SIMPULAN DAN SARAN}

1. Simpulan

Berdasarkan uraian-uraian dalam bab-bab terdahulu, maka ditarik kesimpulan sebagai berikut:

a. Malpraktik merupakan tindakan profesional dari pelayanan kesehatan yang merugikan pihak lain dalam bentuk materil maupun non materil. Malpraktik sendiri timbul akibat dari kurangnya pengetahuan, faktor ekonomi, dan faktor rutinitas, hal ini sangat berpotensi terjadinya malpraktik dalam tindakan medis itu sendiri, dan akibat hukum itu terjadi apabila tenaga medis terbukti melakukan tindakan malpraktik atau perbuatan pelanggaran hukum dalam profesi kedokteran, maka tenaga medis tersebut akan dituntut secara hukum adminitrasi, hukum perdata dan hukum pidana, selain itu juga ada sanksi hukum terhadap tindakan malpraktik oleh tenaga medis yakni, sanksi pidana, sanksi perdata, sanksi administrasi dan sanksi moral, dimana semua sanksi ini akan di terima oleh tenaga medis yang melakukan kelalaian atau pelanggaran hukum terhadap pasien. Untuk mengurangi terjadi malpraktik oleh tenaga medis harus terus meningkatkan pengetahuan terhadap tenaga medis dalam melakukan tindakan kesehatan terhadap masyarakat dan pelayanan kesehatan yang sudah sesuai dengan standar operasional yang berlaku dan menyediakan sarana prasarana yang lengkap untuk menunjang kinerja dari tenaga medis itu sendiri dalam melakukan pelayanan medis terhadap pasien.

b. Untuk mencegah dan menyelesaikannya, Undang-undang Nomor 29 Tahun 2004 tentang praktek kedokteran dan Undang-undang Nomor 36 Tahun 2009 tentang kesehatan sudah jelas mengatur tentang perlindungan hukum terhadap tenaga medis dan sanksi hukum terhadap tenaga medis itu sendiri, oleh kerena itu adanya peraturan tersebut diharapkan hukum tampil demi perlindungan dan kenyamanan semua pihak, untuk itu perlindungan hukum terhadap pasien dan tenaga medis harus benar-benar diterapkan dan benar-benar memberikan kepastian hukum terhadap siapa saja yang merasa dirugikan, dan tenaga medis pun harus memiliki kemampuan, keahlian dan pengetahuan yang luas di bidang kesehatan sehingga tidak terjadinya sesuatu yang tidak diinginkan, seperti adanya dugaan malpraktik yang dilakukan oleh tenaga medis.

2. Saran

Adapun saran yang dapat diberikan berdasarkan pembahasan masalah antara lain:

1. Perlu diperhatikan secara menyeluruh terhadap sarana prasana dalam rumah sakit untuk menunjang tenaga medis dalam bekerja, agar kecil kemungkinan terjadinya malpraktik tersebut. 
2. Perlu adanya sinergitas dalam pelayanan kesehatan antara pasien dan tenaga medis, agar saling terbuka dalam kegiatan pelayanan kesehatan tersebut.

3. Terhadap tenaga medis agar tetap fokus pada profesinya dan terus menerus mengembangkan dan meningatkan profesionalisme dalam bidang kesehatan untuk memberikan yang terbaik sesuai harapan semua masyarakat, dan terhadap kelalaian dan kesengajaan tenaga medis dalam melakukan tindakan malpraktik harus diberikan sanksi sesuai dengan peraturan perundang-undangan yang berlaku.

\section{DAFTAR PUSTAKA}

Andryawan. (2016). Kedudukan Majelis Kehormatan Disiplin Kedokteran Indonesia (MKDKI) dan Konsil Kedokteran Indonesia (KKI) dalam Penegakan Disiplin Kedokteran di Indonesia (Studi Putusan Mahkamah Agung RI Nomor: 298K/TUN/2012). Jurnal Ilmiah Ilmu Hukum, 14(2), 1-31.

Arifko, J. (2014). Kesehatan (Teori dan Aplikasi) di Lengkapi Kesehatan dan Keperawatan. IN Media.

Badlrujaman, M. (2001). Kompilasi Hukum Perikatan. Citra Aditysa Bakti.

Fitriono, R. A., Setyanto, B., \& Ginting, R. (2016). Penegakan Hukum Malpraktik Melalui Pendekatan Mediasi Penal. Yustisia, 5(1), 87-93.

Hadi, I. G. A. A. (2018). Perbuatan Melawan Hukum dalam Pertanggungjawaban Dokter terhadap Tindakan Malpraktik Medis. Jurnal Yuridis, 5(1), 98-113.

Kijanti, N. (2009). Penyelesaian Hukum dalam Malpraktik Kedokteran. Pustaka Yustisia.

Michel, O., \& Mangkey, D. (2014). Perlindungan Hukum Terhadap Dokter Dalam Memberikan Pelayanan Medis. Lex Et Societatis, 2(8), 14-21.

Mucthar, M. (2016). Etika Profesi dan Hukum Kesehatan, Perspektif Profesi Bidan dalam Pelayanan Kebidanan di Indonesia. Pustaka Baru Pers.

Nurdin, M. (2015). Perlindungan Hukum Terhadap Pasien Atas Korban Malpraktek Kedokteran. Jurnal Hukum Samudra Keadilan, 10(1), 92-109.

Riza, R. A. (2018). Tanggung Jawab Dokter terhadap Pasien dalam Hal Terjadinya Malpraktik Medik Dilihat Dari Perspektif Hukum Perdata. JCH (Jurnal Cendekia Hukum), 4(1), 1-8.

Sibarani, S. (2017). Aspek Perlindungan Hukum Pasien Korban Malpraktik Dilihat Dari Sudut Pandang Hukum Di Indonesia. Justitia et Pax, 33(1), 1-22.

Syah, M. I. (2019). Tuntutan Hukum Malpraktik Medis. Bhuana Ilmu Popular.

Trisnadi, S. (2016). Perlindungan Hukum Profesi Dokter Dalam Penyelesaian Sengketa Medis. MasalahMasalah Hukum, 45(2), 150-156. 